\title{
Chinese Activities and Chinese Culture Within Community Arts in Melbourne
}

\author{
Lingliang Li \\ School of Design, East China Normal University, Shanghai, China
}

Email address:

lilingliang91@163.com

To cite this article:

Lingliang Li. Chinese Activities and Chinese Culture Within Community Arts in Melbourne. International Journal of Literature and Arts. Vol. 5, No. 4, 2017, pp. 40-45. doi: 10.11648/j.ijla.20170504.14

Received: June 13, 2017; Accepted: July 15, 2017; Published: August 11, 2017

\begin{abstract}
The purpose of this paper is to analyze current problems in the development of Chinese activities in community arts in Melbourne, including publicity issues. It can be a big subject to find out the way for Box Hill Community Arts Centre to attract Chinese and others to participate in activities. The more this is done, the more Chinese people might expect Chinese culture to be better integrated into individual communities and across communities. Community arts can have an important role to play in this.
\end{abstract}

Keywords: Chinese Activities, Chinese Culture, Community Arts, The City of Melbourne

\section{Introduction}

Australia has a large number of immigrants and a large multicultural population. With the discovery of gold in 1850 , Chinese immigration increased significantly. Importantly, from data obtained by the Australian Bureau of Statistics, there are 669,890 Chinese people in Australia [1]. As Australia's second largest capital city Melbourne is home to a large percentage of this Chinese population. Chinese people have shared their diverse experiences, histories, various festivals, arts, food and culture to create a richer Australia [2] Over the years, many aspects of Chinese culture have been integrated into Australian culture. Today, more and more Chinese people are taking part in community arts activities.

In multicultural Melbourne, a large proportion of Chinese live in Box Hill. In what follows, the author will focus on the Box Hill Community Arts Centre where a variety of activities involving the Chinese community are occurring. The author wants to look at why Chinese people go to this community arts centre; and how they come to know that it offers activities that might attract them.

The purpose of this paper is to analyze current problems in the development of Chinese activities in community arts in Melbourne, including publicity issues. It can be a big subject to find out the way for Box Hill Community Arts Centre to attract Chinese and others to participate in activities. The more this is done, the more Chinese people might expect Chinese culture to be better integrated into individual communities and across communities. Community arts can have an important role to play in this.

\section{The Development of Chinese Activities and Chinese Culture in Community Arts in Melbourne}

Queensland Community Arts Network (QCAN) states that 'All cultures are essentially equal, and society should not promote anyone as superior to the others. Diversity is a social asset, part of the cultural commonwealth, requiring protection and nourishment' [3]. The paper adds that culture is an effective method for social transformation, one that can reduce the polarization and the creation of a deeper connection than any other in the field of change. Likewise, 'A people's survival is measured by its culture, that is, the things the people produce and the beliefs and values they hold. Some cultures disappear when people move from one country to another.' [4]. This has not occurred with the Chinese. This is because Chinese people generally go out of their way to ensure that their children inherit their culture. Chinese culture and Chinese activities have been integrated gradually into community arts in Melbourne. 


\subsection{Current Situation of Chinese Culture in Community Arts}

The City of Melbourne's City Plan sets out that 'Culture is essentially about a way of life. It is a celebration of what a community is, where it has come from and where it is going its identity and memory. It is also about how the City and its community do things and what they value' [5]. The City of Melbourne preferably demonstrates the excellence of arts and the innovation of arts in order to encourage, support as well as promote the contemporary arts and different types of cultural activities. It also reflects diversity in Melbourne and its living culture and also maximizes community involvement [5].

On the other hand, in modem and multicultural Australia, the Commonwealth Government maintains that they could stimulate and look forward to different cultural groups or communities to share their characteristic heritage and culture with their Australians or other foreigners [6]. The Commonwealth Government has already put more emphasis on sharing various cultures and integrating steadily into communities. Then, Chinese culture just like China which is a developing country are spreading in the world. Therefore, Chinese culture and Chinese activities as a foreign culture are developing in community arts in Melbourne. For example, the Box Hill Community Arts Centre, Shire of Bendigo (which is about 160 kilometres from Melbourne), Chinese Museum (which is located in the heart of Melbourne's Chinatown) and other community arts centers have already generated a variety of Chinese activities and Chinese culture.

In addition, the Consulate-General of the People's Republic of China in Melbourne claims that Chinese communities should preserve and advocate excellent Chinese culture [7]. Meanwhile, the development of Chinese culture and Chinese activities is an ongoing practice. This is because it is advantageous for community arts to create a large number of new knowledge and have more opportunities to creatively shape the future [3]. We need to make more efforts to develop Chinese culture and Chinese activities so that it could be better integrated into individual communities and across communities.

\subsection{The Forms of Chinese Activity in Community Arts}

Chinese culture is one of the oldest cultures in the world and Chinese activity is a part of Chinese culture. Importantly, Chinese activities and Chinese culture have blended in with the community arts in Melbourne at present. Furthermore, 'Cultures change through interactions with other cultures and the environment' [8]. However, Chinese culture and Chinese activities have not changed a great deal and do not combine with other cultures. With the development of Chinese culture within community arts, they have their own different forms of Chinese activities and an increasing number of Chinese people and others participate in these activities.

The form of these Chinese activities can be divided into two sections including cultural activity and physical activity.

Cultural activites: There are traditional festivals including
Chinese spring festival, Mid-autumn festival, Dragon boat festival; Cantonese Opera; Chinese brush painting; Chinese calligraphy and so on.

Physical activities: Social dance; Tai Chi; Fan dance; Chinese choir; Dancing group and so on.

\section{The Introduction of Box Hill Community Arts Centre and Types of Chinese Activities}

I have chosen to focus on the Box Hill Community Arts Centre as an example because a large proportion of Chinese live in Box Hill and there are a lot of different Chinese activities happening.

\subsection{The Introduction of Box Hill Community Arts Centre}

The Box Hill Community Arts Centre was established in 1987. Three years later, a new purpose-built architectural building was completed and the Community Arts Centre was opened in October. Since opening, the Box Hill Community Arts Centre has focused on different cultural activities within the City of Whitehorse, winning architectural and lifestyle awards in the process. The centre provides a wide range of services, including activities for adults and children during school term and a wide range of art or craft activities during the school holidays. In addition, they have a variety of Chinese activities including Chinese music, Chinese dancing, Chinese brush painting, Chinese traditional activities, exhibitions and so on. The Community Arts Centre also offer their rooms for hire for regular or casual use. In terms of population, one third of Chinese people living in the City of Whitehorse take part in the Box Hill Community Arts Centre, because most of the Chinese people are mainly concentrated and living in the Box Hill. On the other side, the community arts centre is located in Station Street which is near the Box Hill shopping centre. It is a benefit for them to attract an increasing number of people to participate in the community arts centre [9].

\subsection{Types of Chinese Activities}

The Box Hill Community Arts Centre possesses different types of Chinese activities including Chinese music, Chinese dancing, Chinese brush painting, Chinese traditional activities, as well as exhibitions and other Chinese activities.

\subsubsection{Music: The Melbourne Chinese Choir and Melbourne Taiwanese Ladies Association}

Many community groups run activities and programs at Box Hill Community Arts Centre like performing arts. For instance, the Melbourne Chinese Choir is a multitudinous group of performers devoted to happening the traditions of Chinese music culture, which is established in 1991. The choir has developed their enjoyment for western as well as contemporary and traditional Chinese folk music. For Melbourne Taiwanese Ladies Association, their members could learn and practice traditional and modern Chinese 
songs and also conduct community performances during this year.

\subsubsection{Dancing: Taiwanese Women's Dancing Club}

Taiwanese Women's Club learns and practices traditional and modern Taiwanese dance. For instance, this group processes fan dance, social dance and folk dance. Members are taught by a senior dance teacher who comes from China. It is beneficial for their members to increase their self-esteem and confidence. Dancing is also a good exercise and the best way for people of all ages to keep fit and stay in shape.

\subsubsection{Drawing: Chinese Brush Painting}

Chinese brush painting is one of the oldest forms of painting in the world. Since 4000 B. C., Chinese brush painting has developed over more than 6000 years. Through learning the unique art of Chinese brush painting, these members will know about basic brushstrokes and techniques using ink on rice paper. Then, they could learn how to draw a flower or draw prawns on rice paper. When they have more practice and accumulate more experience, they could copy some outstanding and famous paintings including 'Prawns' by Chi Baishi. The workshop will provide any of materials.

\subsubsection{Traditional Activity: Chinese Spring Festival}

Nowadays, an increasing number of Australians celebrate Chinese New Year with Chinese people. So, the Box Hill Community Arts Centre and White Horse Town Hall hold a traditional activity: Chinese Spring Festival in the Box Hill Centre each year. There are a lot of traditional activities, for example, lion dancing, folk dancing, musical performance, guessing lantern riddles and so on. It is beneficial for Chinese people to celebrate their festival and ensure that their children inherit their culture.

\subsubsection{Other Activities: Textile-'Art Without Borders-Free Workshops for Migrant Women'}

Textile is a famous and traditional Chinese activity and this is a kind of personal skill in China. More and more Chinese people are willing to attend textile workshops to learn how to knit a sweater or how to do the cross-stitch. Therefore, textile becomes more and more popular in our lives.

A majority of women, who are newly arrived migrant, will be invited to attend free textile workshops, to explore in a creative way their personal journey from country of birth to their new home here in Australia. Textile workshops will be held from 14th July to 15th September 2014. If members have no any experience in textile, it is not necessary and everyone could take part in this workshop to enjoy it.

\subsubsection{Exhibition: Chinese Brush Painting-'Wind of Change' $^{\prime}$}

An exhibition planned for later this year is 'Wind of Change'. This is a new direction in Chinese brush painting that will be held from 16th October to 8th November 2014., The 'Wind of Change' exhibition uses traditional brush-stroke techniques with colors and inks on rice paper.

This exhibition is celebrated local artist Echo $\mathrm{Wu}$ who has been teaching Chinese Brush Painting in a lot of places including the Whitehorse, Box Hill Community Arts Centre and Vermont South Community House over the years. Participants are Echo $\mathrm{Wu}$ and some of her advanced students. Viewers will be absorbed in appreciating paintings throughout the exhibition.

\section{Investigation of Activity Publicity}

\subsection{Box Hill Community Arts Centre}

The author interviewed Kathy (the manager in the Box Hill Community Arts Centre) and she told me 'We always use E-mail, website, facebook and put brochures in other community arts centers and libraries.' In other words, the Box Hill Community Arts Centre uses web forms and general publicity methods to let people know about their Chinese activities.

Nowadays, network technology is more and more developed. When you type some key words on the Internet, you will search a large number of useful information that you want. The Box Hill Community Arts Centre via web forms including Email, official website and Facebook to introduce background and publicize their a variety of workshops or other activities. Moreover, you will gain some essential information such as others' comments and reviews about these Chinese activities and this community arts centre.

In terms of traditional or general publicity methods, Box Hill Community Arts Centre pastes up posters outside as well as puts up in the Box Hill Shopping Centre in order to attract more audience and visitors to participate in these Chinese activities. This community arts centre also put brochures and catalogues in other community arts centers and libraries. It is advantageous for them to better broadcast their community arts centre and let more and more people know.

\subsection{Members in the Box Hill Community Arts Centre}

The author investigated their members who participated in the class of Chinese activities in the Box Hill Community Arts Centre and contacted other people who did not take part in Chinese activities by e-mail.

Member A: 'l live in the Box Hill over more than eight years. Um... 1 take part in this community arts centre because my friends have engaged in this centre and tell me about these Chinese activities. So, 1 am interested in and have became to be a member in the Box Hill Community Arts Centre.'

Member B: '1 know these Chinese activities through the Internet as their official website has a large amount of details about various of activities. Afterward, 1 see the 'Membership Drive' poster in the Box Hill Shopping Centre.'

Member C: 'My friend told me about these Chinese activities and then 1 searched on their official website. 1 thought these activities could be interesting so that 1 participated in the Box Hill Community Arts Centre.'

To sum up, these members have different ways to know about that the Box Hill Community Arts centre has various 
types of Chinese activities. Using verbal description, searching the official website of the Box Hill Community Arts Centre, finding the 'Membership Drive' poster in the Box Hill Shopping Centre and communicating with this community arts centre by e-mail. Although the Box Hill Community Arts centre via four methods to attract Chinese people to participate in these Chinese activities, the way of publicity is very simple. It will effect this community arts centre to recruit a lot of members and it also effect members to achieve a great deal of information about these Chinese activities.

\section{Problems, Analysis and Summarize the Development of Chinese Activities in Community Arts in Melbourne}

\subsection{Problems}

\subsubsection{Lack of New Chinese Activities}

Although the Box Hill Community Arts Centre has diverse forms of Chinese activities including music, painting, dancing, exhibitions and traditional activities, there are not any other new Chinese activities happening. In general, they only have the dancing club, Chinese brush painting, the Chinese choir, Chinese spring festival and other traditional activities. Namely, their members could be bored with these Chinese activities as these programs are rather dull. As a result, this community arts centre could not appeal to their members and then a growing number of members are unwilling to participate in Chinese activities in the Box Hill Community Arts Centre. Consequently, it is detrimental to their future development and it is disadvantageous for them to attract more Chinese members.

\subsubsection{Lack of Communication with Other Community Arts Centres}

Kathy (2014, pers. comm., 1 May) (the manager in the Box Hill Community Arts Centre) said 'Community arts centres are all individuals so that they have their own business and plan their own projects as well as activities.' Because of this, they always complete these projects by themselves and do not collaborate with other community arts centres. Meanwhile, the Box Hill Community Arts Centre seldom contact with other community arts centers. This is because some of Community Arts Centres have less or no Chinese activities. So, if the Box Hill Community Arts Centre wants to hold a Chinese activity, they might do it by themselves. On the other hand, distance may be another problem. For instance, as we all know, the Shire of Bendigo has a lot of Chinese activities and has a Golden Dragon Museum. However, it is very far which is about 160 kilometers from Melbourne. Therefore, lack of communication with other community arts centres that is the biggest issues in the community arts centres.

\subsubsection{Publicity Issues}

The method of publicity is very simple. The publicity issue is one of the most important management problems in the Box Hill Community Arts Centre. Through investigating this community arts centre and interviewing Kathy ( the manager in the Box Hill Community Arts Centre), 1 find the method of publicity in the community arts centre is very simple. They always use web forms to let people know about their Chinese activities and sometimes general publicity methods. The method of publicity is too simple to gain result effectively.

In my opinion, 1 think general publicity methods are more necessary than web forms. When you go to the Box Hill Shopping Centre or walk on the street, it is hard for you to see the poster about the Box Hill Community Arts Centre. In addition, Some of people rarely search on the Internet including the elderly. Although they have posters about their Chinese activities and their 'Membership Drive' in the shopping centre, you could not see it if you do not find carefully. Therefore, lack of posters are not beneficial for the community arts centre to attract more Chinese members. General publicity methods are the direct way to make people know about essential information.

Slowly let people know these Chinese activities. The Box Hill Community Arts Centre use a variety of methods to contact with their members and let them know about new Chinese activities. Whereas, using e-mail could not be a better way to contact with their members. This is because they could not directly contact them even if this community arts centre has a great deal of Chinese members but. It could decrease the degree of the publicity. At the same time, they do not immediately let other people (not members) know these activities. These people want to take part in the Chinese activity after members or friends tell them. It is very late and it could miss an opportunity to enjoy the Chinese activity.

\subsection{Analysis and Summarize the Development of Chinese Activities in Community Arts in Melbourne}

Queensland Community Arts Network (QCAN) maintains that the development of culture can be defined as a collective process [3]. This contribution changes people's lives as well as it is beneficial for a community to develop for a long term. As mentioned, Chinese culture and Chinese activities are developing in community arts in Melbourne. However, it has a large proportion of current problems in the development of Chinese activities in community arts in Melbourne, including publicity issues, lack of new Chinese activities and lack of communication with other community arts centres. It also provides some advices with the following sections which could help the community arts centre to do the better in the future.

\subsubsection{Creating New Chinese Activities and Promoting Publicity}

The author found that although the Box Hill Community Arts Centre has different kind of Chinese activities, they need to think about more and more new Chinese activities in order to accumulate an increasing number of Chinese members and non-Chinese members. For instance, the Box Hill 
Community Arts Centre could hold more traditional Chinese festivals including Dragon Boat Festival and Lantern Festival Chinese members and non-Chinese members could learn how to wrap up rice dumplings and know about the Chinese customs in the Dragon Boat Festival. Chinese people also generally go out of their way to ensure that their children inherit their culture. On the other hand, the Box Hill Community Arts Centre needs to put more emphasis on the publicity. They could paste up posters in the busy place such as the Box Hill Shopping Centre and other community arts centres or other libraries. It is good for them to attract more members so that the Chinese culture could be integrated into community arts and let people know about the Chinese culture.

\subsubsection{Contacting with Other Community Arts Centre Frequently}

Based on my research, the author found that although the Box Hill Community Arts Centre has different types of Chinese activities and an increasing number of Chinese people participate in these activities, it seldom communicates with other community arts centres. In my opinion, The author think it need to make more contact with other community arts centres, like Shire of Bendigo, Doncaster and Footscray, to share what Chinese activities it is offering. For example, the Shire of Bendigo (which is about 160 kilometers from Melbourne), has since the Gold Rush days of the 1850s had a strong association with the Chinese. It would be nice if Chinese people in Box Hill and other areas could share in this as well. And it would be nice if non-Chinese people also became more familiar with the many aspects of Chinese culture that can be seen throughout Victoria.

\section{Compare with the Shire of Bendigo}

The Golden Dragon Museum is located in the Shire of Bendigo (which is about 160 kilometers from Melbourne), which is the largest and oldest Chinese Cultural Centre of Australia. This museum was established in 1991 and preserved a great deal of Chinese Culture in Australia. There are different types of Chinese activities and exhibitions about Chinese culture in the museum [10].

Compared the Box Hill Community Arts Centre to the Shire of Bendigo, it can clearly be seen that the Shire of Bendigo is a typical Chinese Cultural Centre of Australia. For Chinese culture and Chinese activities, visitors could have a historical tour to appreciate cultural relics with a long history and visit Chinese style architectures including Yi Yuan Gardens and Kuan Yin Temple. If you know about more knowledge about China or Chinese people are willing to let their children understand their own culture, the Shire of Bendigo is the best choice that you think about it. In terms of Chinese activities, tea ceremony, Chinese paper cuts, Chinese waist drums which are all traditional and classic activities and the museum has some of educational tours and historical exhibitions.

Furthermore, the publicity of the Shire of Bendigo is better than the publicity of the Box Hill Community Arts Centre. When you communicate with others about Chinese culture within community arts in Melbourne, the majority of citizens or others will associate the Shire of Bendigo. This is because not only does it has typical Chinese activities and classic Chinese style buildings, but also it uses some methods to attract different types of visitors, for example, Chinese people, Australians, tourists and history buffs.

All in all, the Box Hill Community Arts Centre could make more efforts to develop Chinese activities as well as Chinese culture and accumulate more experience from the Shire of Bendigo. This is because the Consulate-General of the People's Republic of China in Melbourne states that it is in favour of developing an increasing number of cultural engagement and knowing between China and Melbourne more deeply [7].

\section{Conclusion}

In conclusion, throughout investigating the Box Hill Community Arts Centre, this paper has analyzed the current problems in the development of Chinese activities in community arts in Melbourne, including publicity issues. Then, the author have listed some recommendations here in order to attract Chinese and non-Chinese to participate in its activities. It is also advantageous for the Chinese culture to develop in the community arts. Certainly, the author is unsure there will be other issues in the development of the Chinese activities and Chinese culture within community arts in Melbourne, but Chinese culture and Chinese activities as a foreign culture are developing in community arts in Melbourne. Of course, diverse Chinese activities and Chinese culture have integrated gradually into the community arts in Melbourne. The more this is done, the more Chinese people might expect Chinese culture to be better integrated into individual communities and across communities. Community arts can have an important role to play in this.

\section{References}

[1] Censusdata 2008, Australian Bureau of Statistics, Censusdata, viewed 13 May 2014,

$<\mathrm{http} / /$ www.censusdata.abs.gov.au/census_services/getproduc t/census/2011/quickstat/2GMEL>

[2] Education and communities 2011, Cinese in Australia, Education and communities, viewed 13 May 2014, $<$ http://www.schoolatoz.nsw.edu.au/homework-and-study/othe r-subjects-and-projects/people-cultures-and-government/chine se-in-australia $>$

[3] Queensland Community Arts Network, Community Cultural Development - What is it? Queensland: Queensland Community Arts Network Inc. Class handout, 2008, pp. 2.

[4] How can Chinese Culture survive in Australia? 2010, Australasian Centre of Chinese Studies, viewed 13 May 2014, $<$ http://www.accschinese.com/accsblog/2010/04/how-can-chin ese-culture-survive-in-australia/> 
[5] Hawkes. J, The fourth pillar of sustainability: Culture's essential role in public planning, Melbourne: Common Ground Publishing, 2001.

[6] Office of Multicultural Affairs, National Agenda for a Multicultural Australia, Sharing Our Future, Canberra: Australian Government Publishing Service, 1989.

[7] "Promoting Excellent Chinese Culture and Showing a Good Image of Overseas Chinese" Forum held in Melbourne 2012, The Consulate-General of the People's Republic of China in Melbourne, viewed 3 June 2014,

$<$ http://melbourne.china-consulate.org/eng/news/t934300.htm>
[8] Chinese Influences on Australia 2010, NEALS, Education and Training, New South Wales, viewed 3 June 2014, $<$ http://www.curriculumsupport.education.nsw.gov.au/primary /hsie/teaching/stage3/s3_assests/s3_china.pdf>

[9] Box Hill Community Arts Centre 2014, Box Hill Community Arts Centre, Melbourne, Victoria, viewed 3 June 2014, $<$ http://www.bhcac.com.au/>

[10] Golden Dragon Museum 2014, Shire of Bendigo, Victoria, viewed 3 June 2014, http://www.goldendragonmuseum.org 